\title{
Humus horizon development during natural forest succession process in the Polish Carpathians
}

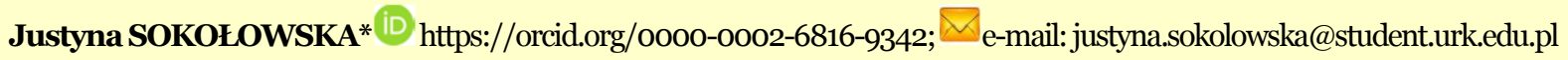 \\ Agnieszka JÓZEFOWSKA (iD https://orcid.org/oooo-0003-4922-2037; e-mail: agnieszka.jozefowska@urk.edu.pl \\ Tomasz ZALESKI iD https://orcid.org/oooo-ooo2-9785-3784; e-mail: tomasz.zaleski@urk.edu.pl \\ ${ }^{*}$ Corresponding author
}

Department of Soil Science and Agrophysics, University of Agriculture in Krakow, al. Mickiewicza 21 31-12o Kraków, Poland

Citation: Sokołowska J, Józefowska A, Zaleski T (2022) Humus horizon development during natural forest succession process in the Polish Carpathians. Journal of Mountain Science 19(3). https://doi.org/10.1007/s11629-021-6836-x

(C) The Author(s) 2022.

\begin{abstract}
As a result of socio-economic changes and land abandonment, the main ecological driver of the Carpathian landscape is the progression of the natural forest succession process. Thus, aspects of this process have become worthy of attention, especially in the context of carbon sequestration and the management of protected areas. Soil processes, especially within the topsoil, are some of the most susceptible to change, due to the accumulation of organic matter during such land-use transformations. The purposes of this study were to investigate the differences in topsoil development using the A Horizon Development Index (ADI) and to study the composition of humic substances and advanced organic matter humification in different land-use areas in selected Carpathian national parks, i.e. Bieszczady, Magura and Pieniny National Parks in southern Poland. Additionally, a goal of this study was to compare the ADI and the spectroscopic coefficients of humic substances as indicators of the degree of humus horizon shaping as well as advanced organic matter humification. In total, ten transects were selected, each consisting of three different land-use areas: semi-natural meadow, successional forest and
\end{abstract}

Received: 09-Apr-2021

$1^{\text {st }}$ Revision: 10-Aug-2021

$2^{\text {nd Revision: 20-Oct-2021 }}$

Accepted: 05-Dec-2021 old-growth forest. Soil colour was determined in fresh and air-dried samples using the Munsell colour chart. In air-dried soil samples $\mathrm{pH}$, soil texture, total organic carbon and total nitrogen were measured. Humic substances were extracted and further characterized by UV-VIS spectroscopy. The ADI confirmed the influence of natural forest succession on soil colour darkening and the development of the uppermost soil layer. Spectroscopic analyses of humic substances showed two different patterns depending on soil depth. In the $0-10 \mathrm{~cm}$ layer, natural forest succession reduced the rate of the humification process and decreased the degree of maturity of fulvic acids; in the $10-20 \mathrm{~cm}$ layer, it led to an increase in the rate of the humification process and a decrease in the content of humic and fulvic acids at the beginning of the transformation. The comparison of two different indicators of soil development - the ADI and the spectroscopic coefficients of humic substances $\left(Q_{4 / 6}\right.$, $\left.Q_{2 / 4}, Q_{2 / 3}, \Delta \log K\right)$ - indicated that these indexes are based on different features of soil and cannot be used interchangeably.

Keywords: Land use changes; Natural forest succession; Polish Carpathians; Landscape transformation; Protected areas management; Humic substances 


\section{Introduction}

Originally, the Carpathians were covered with primary forests. Settlement in these virgin areas of the mountains led to the formation of semi-natural meadows in an initial transformation of the landscape. In the Polish part of the Carpathians, this was related to agriculture, especially the pasture practices of Italian immigrants in the area in the $13^{\text {th }}$ and $14^{\text {th }}$ centuries (Kubijowicz 1927). Later, sheep herding developed in this area; initially, this activity only involved grazing. The development of hay meadows took place in the $18^{\text {th }}$ century; however, a significant rise of pasture activity in the Carpathians was noted from the $19^{\text {th }}$ century to the first half of the $20^{\text {th }}$ century (Hejcman et al. 2012). After World War II and the related socio-economical changes, the abandonment of agricultural land initiated plant succession processes and a reduction in the area of the semi-natural meadows (Zarzycki and Korzeniak 2013), and encroachment of secondary forests to their original territory began to change the unique Carpathian landscape again.

Nowadays, the natural forest succession process is an important ecological driver in the Carpathian landscape as well as a major factor that causes the disappearance of highly ecologically valuable seminatural meadows. Previous studies in the Pieniny National Park have shown that forest succession influences chemical, physical and microbiological soil properties to a slight extent (Sokołowska et al. 2020). However, a deeper look at morphological features may be a simpler way to assess changes in the soil environment without time-consuming laboratory analyses. Soil colour is one of the most commonly assessed features of soil morphology (Buol et al. 2003) and may be an indicator of various other soil properties, although so far, soil colour has been used mostly as an indicator of soil organic carbon (SOC) content in the literature (Konen et al. 2003; Wills et al. 2007).

In soil science, the Munsell colour chart (Oyama and Takehara 1970) is commonly used to determine soil colour. Significant relationships were observed between SOC concentration of intensively farmed soils and the Munsell value and the Munsell chroma measured for moist and air-dried soils (Konen et al. 2003). As noted above, the relationship between soil colour and soil organic matter (SOM) or SOC content is well known; however, in some studies other factors that influence soil colour have been assessed. Novák et al. (2018) have shown some positive correlations between the colour index and soil texture, as well as a negative relation between the colour index and calcium content and also pH. Aitkenhead et al. (2013), using a dataset derived from the National Soil Inventory of Scotland database, determined the relationships between soil colour and a range of physical and chemical soil characteristics. Recently, a new approach of using an inexpensive colour sensor was used to develop SOC and total nitrogen predictions for Russian Chernozems (Mikhailova et al. 2017).

Soil colour measurement has also been used in the investigation of urban soils. Mazurek et al. (2016) determined the stabilization of organic matter (OM) by calculating the A Horizon Development Index (ADI), based on the Munsell value and Munsell chroma of the soil colour. Also, Wills et al. (2007) predicted SOC content using soil colour measurement and presented a simple linear regression of SOC with soil depth, Munsell value and Munsell chroma. Thus, so far soil colour has been widely used to assess various soil properties, but mostly in agricultural or urban ecosystems. Further studies are needed to explore the differences in properties and associations of soil colour for other land uses (Wills et al. 2007). The present study focused on soils undergoing natural environmental processes, i.e. natural forest succession in protected areas such as nature preserves, to contribute to a wider knowledge about using soil colour as a valid descriptive feature in soil science.

It is well known that SOM is a crucial factor in soils, determining soil properties as well as playing a very important role in the development of the soil ecosystem. Organic matter is one of the basic soil pigments, colouring soils black (Vodyanitskii and Savichev 2017). Viscarra Rossel et al. (2006) have shown that the darkening of soils rich in organic carbon is caused by saturated OM, the variation and quantity of black humic acid, as well as soil moisture. Regarding the OM, a very important role is played by polymolecular and polydispersion compounds of polyelectrolytes and spherocolides, called humic substances (Gonet 1993; Hayes and Swift 2001; Kononowa 1968).

Some papers have highlighted the role of humic substances in soil colour. According to Lindbo et al. (1998), the composition of humic substances is one of the factors influencing the degree of soil darkening. Vodyanitskii and Kirillova (2016) highlighted that the 
pigmenting ability of humic acids is greater than that of fulvic acids. Thus, changes in soil colour during natural forest succession could be provoked by humic substance composition as well as changes in humic substance structure.

One broadly used method to assess changes in humic substances caused by environmental factors is absorption spectrophotometry in the UV-visible (UVVIS) range. This method allows qualitative analyses of humic substances (Gołębiowska 2004); moreover, appropriate analysis of UV-VIS spectra may provide very interesting information on the chemical structure of humic substances (Kumada 1987; Stevenson 1994). The $Q_{4 / 6}, Q_{2 / 4}, Q_{2 / 3}$ and $\Delta \log K$ are the most common coefficients calculated from the results of absorption spectrophotometry in the UV-VIS range. The $\mathrm{Q}_{4 / 6}$ is considered as an indicator of humus quality and humification degree (Pospíśilová et al. 2014). According to Orlov (1983), higher $Q_{4 / 6}$ values show a lower molecular weight and lower degree of condensation of aromatic structures. The $Q_{2 / 4}$ coefficient reflects the proportion between lignins and other materials at the beginning of humification as well as the content of materials at the beginning of transformation stage (Erraji et al. 2017). The $Q_{2 / 3}$ indicates the degradation of humic substance structures; higher $Q_{2 / 3}$ values reflect a higher degree of degradation (Golębiowska 2004). Finally, the $\Delta \log \mathrm{K}$ indicates the level of humic substance maturity (Wnuk et al. 2020).

Humic substances, based on their solubility, are divided into humic acids (HA), which are non-soluble at low $\mathrm{pH}(<2)$; fulvic acids (FA), which are soluble at acidic and alkaline conditions; and humins, which are non-soluble in both acidic and alkaline conditions. To better understand the nature of humic substances, Mohinuzzaman et al. (2020) examined different methods for humic substance extraction from soils from varying land uses and provided useful information about labile and insoluble humic substance fractions. Moreover, Mohinuzzaman et al. (2020) and Mostofa et al. (2019) studied the fluorescence features of humic acids and fulvic acids, which are very useful for a better understanding of biochemical transformations and consequences in diverse soil environments.

Humic substances have been considered as a suitable soil fraction to provide information about SOC levels in environmental studies (JiménezGonzález et al. 2020). As stated by Sun et al. (2012), changes in land use can alter the chemical composition of humic substances despite their resistant nature to biological degradation. Kukuls et al. (2019) examined the influence of land afforestation on humic substances and saw a gradual decrease in the ratio of carbon of humic acids and fulvic acids $\left(\mathrm{C}_{\mathrm{HA}}: \mathrm{C}_{\mathrm{FA}}\right)$ after land-use changes. Several studies (Panettieri et al. 2014; Tadini et al. 2015) have especially highlighted the role of humic acids as including molecular components of plant and microbial origin and showing their different compositions in various soils. So far, humic substances have been the object of study around the world, e.g. in Europe in arable lands and grasslands (Ukalska-Jaruga et al. 2019) and afforested agricultural lands in the boreal-nemoral ecotone (Kukuls et al. 2019); in Asia (Navarrete et al. 2010); as well as in South America (Zalba et al. 2016). Zhiyanski et al. (2017) examined the effects of management intensity and different land uses on quantitative and qualitative features of soil humic and highlighted the importance of such research in mountain ecosystems.

However, changes in humic substance composition during the natural forest succession process are still unknown. Therefore, this study investigated how the content and composition of humic substances may be altered during natural forest succession, extending the knowledge about soil changes during land-use change, especially topsoil, which is the most susceptible to changes due to the short-term accumulation of various kinds of OM. In meadows, for instance, topsoil incorporates easily decomposed grass and herbaceous plants; in successional forests, fresh litterfall from young trees; and in old-growth forest - a climax stage - a constant supply of fresh litter, and these should be mirrored as changes in soils resulting from different land uses.

The purpose of this study was to test the following hypotheses:

1) Natural forest succession influences topsoil development, as expressed by ADI values.

2) The composition of humic substances varies in soils from different land uses (semi-natural meadow, successional forest, old-growth forest) and soil layers (0-10 and $10-20 \mathrm{~cm})$.

3) Advanced OM humification differs between land uses and the examined soil layers ( $0-10$ and $10-$ $20 \mathrm{~cm}$ ).

4) The ADI and UV-VIS spectroscopic coefficients are suitable and comparable indicators to 
determine the degree of humus horizon shaping as well as advanced OM humification.

\section{Materials and Methods}

The research was conducted in the Polish Carpathians, southern Poland. The soil samples were taken from three Carpathian national parks Bieszczady National Park (BdNP), Magura National Park (MNP) and Pieniny National Park (PNP) (Table 1). The precise characteristics of these sites with particular attention to soil cover were presented in previous studies: BdNP (Skiba 1999), MNP (Skiba and Drewnik 2000) and PNP (Niemyska-Łukaszuk et al. 2002). In total, ten transects, each consisting of three different land-use areas: 1) semi-natural meadow, 2) successional forest covered by different aged (25- to 75-year-old) trees and 3) old-growth forest (aged more than 150 years), were selected. Table 1 shows the precise GPS location as well as elevation and slope of the investigated succession areas, while the nearest meadows and forests adjacent to the selected succession area were also assessed. The transects were selected based on historical data as well as historical maps, available present-day satellite maps (https://geoportal36o.pl/) and database (https://www.bdl.lasy.gov.pl) covering the study area. The semi-natural meadows were created in the $13^{\text {th }}$ and $14^{\text {th }}$ centuries as a result of tree cutting and maintained by pasture and agriculture. They are formed mostly by native species which have spread across the landscape (Zarzycki and Korzeniak 2013). The natural forest succession areas were created as a result of encroachment of successional plants on abandoned semi-natural meadows. They contain tree species such as Acer pseudoplatanus L. (sycamore maple), Betula pendula Roth (silver birch), Populus tremuloides Michx. (aspen poplar), Picea abies L. (Norway spruce), Alnus incana L. (grey alder), Pinus sylvestris L. (Scots pine), Abies alba Mill. (silver fir) and Fraxinus excelsior L. (common ash) dominated by of Fagus sylvatica L. (common beech). The oldgrowth forest stands belonged to one of the most common forest habitats in the Carpathians - Dentario glandulosae-Fagetum (Carpathian beech forest). Example photographs of the semi-natural meadow, natural successional forest and old-growth forest plots are provided as Appendix 1.

After removing fresh leaf fall from the surface, soil samples were collected using a metal $5 \mathrm{~cm}$ diameter core (Appendix 2) from the $0-20 \mathrm{~cm}$ layer of soil. Then the soil core was divided into two layers, $0-10 \mathrm{~cm}$ and 10-20 $\mathrm{cm}$. The soil cores were collected from all ten transects (Table 1) in five repetitions from each of semi-natural meadow, successional forest and oldgrowth forest area. Soil colour was determined in fresh and air-dried samples using the Munsell colour chart

Table 1 Location of the three study areas, along with topographical (elevation, slope) and climatic conditions (temperature, rainfall, climate classification)

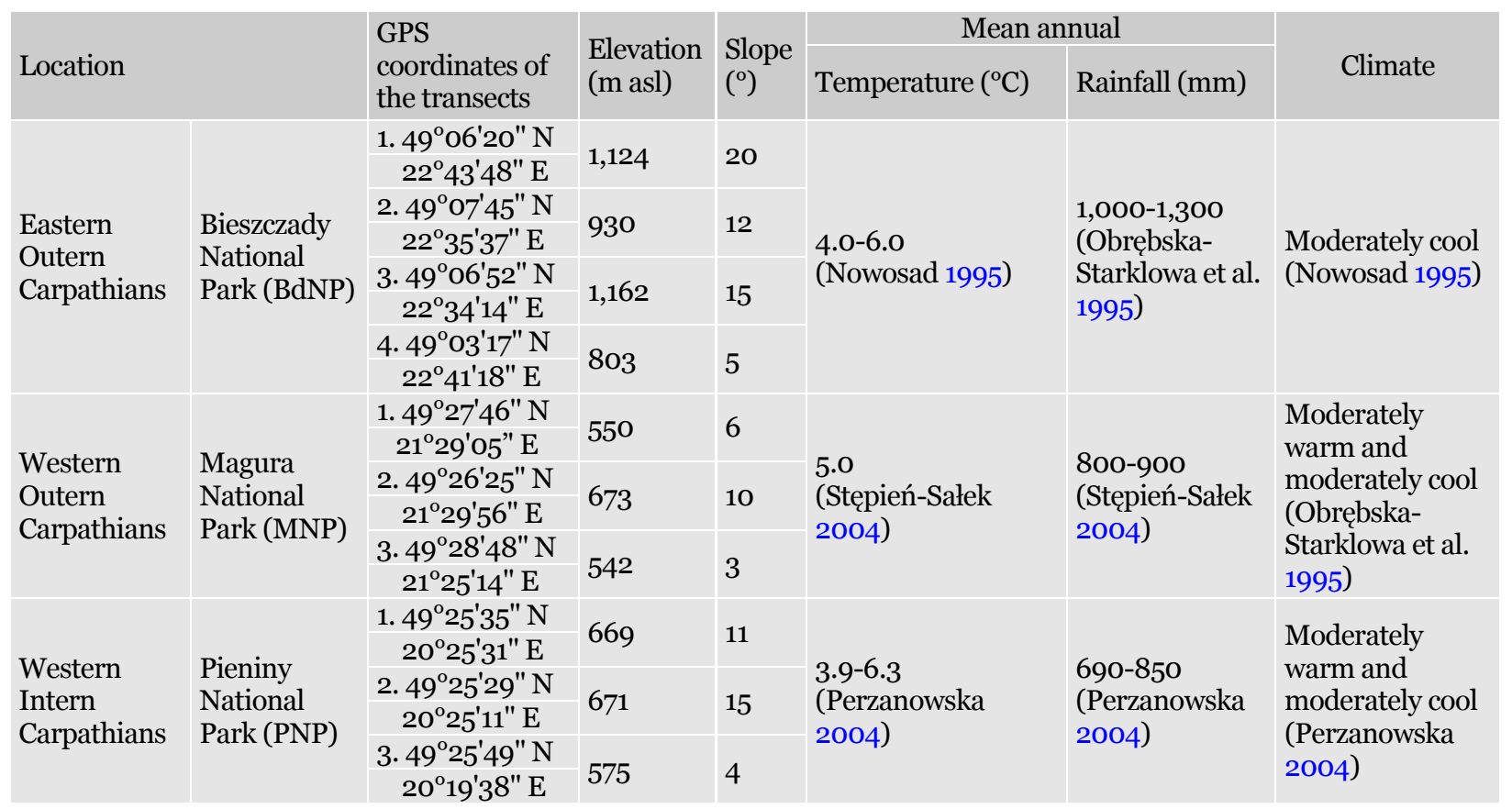


(Oyama and Takehara 1970). Based on the wet and dry soil colour - i.e. the value and chroma in the individual soil layers $(0-10 \mathrm{~cm}$ and $10-20 \mathrm{~cm})$ - the ADI was calculated according to the following equation:

$$
\mathrm{ADI}=\frac{\text { horizon thickness }}{V \times C}+1
$$

where $V$ is Munsell value and $C$ is Munsell chroma (Mazurek et al. 2016).

In our study, each of the examined layers was 10 $\mathrm{cm}$ thick, so the ADI values in this case indicated only the differences in soil colour and did not depend on soil layer thickness. The extraction of humic substances (humic and fulvic acids) was performed in air-dried soil samples, sieved with a mesh size of 2 $\mathrm{mm}$, using the procedure recommended by the International Humic Substance Society (Tan 2005). The extraction of humic substances was performed on three replicates from each collected soil sample. The carbon from the mixture of humic substances (the sum of humic and fulvic acids $\mathrm{C}_{\mathrm{HA}+\mathrm{FA}}$ ) was extracted in an alkaline solution (o.1 $\mathrm{M} \mathrm{NaOH}$ ) for 4 hours. The carbon of humic acids $\left(\mathrm{C}_{\mathrm{HA}}\right)$ was precipitated and separated after acidification of humic substances solution by $6 \mathrm{M} \mathrm{H}_{2} \mathrm{SO}_{4}$ to $\mathrm{pH}=1.5$, and next diluted in $0.1 \mathrm{M} \mathrm{NaHCO}_{3}$. The carbon of fulvic acids $\left(\mathrm{C}_{\mathrm{FA}}\right)$ were obtained as a supernatant after separation from the humic acids. The content of organic carbon in obtained solutions of humic substances was measured using a Euro Thermo TOC-TN 1200 (Landsmeer, Netherlands). The non-extractable organic carbon $\left(\mathrm{C}_{\mathrm{NE}}\right)$, defined as the humins, was calculated by the difference between total organic carbon ( $\mathrm{C}_{\text {org }}$ ) and CHA+FA.

The obtained $\mathrm{C}_{\mathrm{HA}}$ and $\mathrm{C}_{\mathrm{FA}}$ solutions were further characterized by UV-VIS spectroscopy, using a
Shimadzu UV-180o (Kyoto, Japan) spectrophotometer UV-VIS. Based on the measured absorption spectra the following coefficients were calculated: 1) $Q_{4 / 6}$ representing the quotient of absorbance values at wavelengths $400 \mathrm{~nm}$ and 600 nm (Schnitzer and Khan 1972); 2) $\mathrm{Q}_{2 / 4}$ expressing of absorbance values at wavelengths $280 \mathrm{~nm}$ and 400 nm (Gonet and Dębska 1998); 3) $\Delta$ log K calculated following the equation:

$$
\Delta \log \mathrm{K}=\log \mathrm{K}_{400 \mathrm{~nm}}-\log \mathrm{K}_{600 \mathrm{~nm}}
$$

where $\mathrm{K}$ is absorbance value at $400 \mathrm{~nm}$ and $600 \mathrm{~nm}$ (Kumada 1987); and 4) $\mathrm{Q}_{2 / 3}$, expressed as a ratio of absorbance values at wavelengths $250 \mathrm{~nm}$ and 365 nm (Suhett et al. 2004).

Additionally, in the air-dried soil samples, soil properties of two replicates for each soil sample were measured such as: $\mathrm{pH}$ in $1 \mathrm{M} \mathrm{KCl}$ (in the $1: 2.5$ ratio) by the potentiometer method, using combined electrode Hydromet type ERH-12-6 (Gliwice, Poland); soil texture (sand, silt, clay) according to the Casagrande-Prószyński aerometer method; total organic carbon ( $\mathrm{C}_{\mathrm{org}}$ ) content using the Tiurin method (Kabała and Karczewska 2017); and total nitrogen $\left(\mathrm{N}_{\text {tot }}\right)$, using a FOSS Kjeltec ${ }^{\mathrm{TM}} 8100$ (Höganäs, Sweden) (Lityński et al. 1976). Investigated soils were classified according to the World Reference Base (IUSS Working Group WRB 2015). Almost all soils, except for two, were classifiable as cambisols with a varied trophicity (dystric and eutric cambisols) (Table 2). The other two soils were classified as leptosols with a not-fully-shaped cambic horizon.

Statistical analyses were performed using Statistica 13.0 software. Means and standard errors of the various measured properties were calculated for

Table 2 Soil units at the area of the transects according to World Reference Base for Soil Resources (WRB)

\begin{tabular}{|c|c|c|c|c|}
\hline \multirow{2}{*}{$\begin{array}{l}\text { Study } \\
\text { site }\end{array}$} & \multirow{2}{*}{$\begin{array}{l}\text { Number of } \\
\text { transect }\end{array}$} & \multicolumn{3}{|c|}{ Land use } \\
\hline & & Meadow & Succession & Forest \\
\hline \multirow{4}{*}{ BdNP } & 1 & $\begin{array}{l}\text { Dystric Endoskeletic } \\
\text { Endostagnic Cambisols }\end{array}$ & Dystric Endoskeletic Cambisols & Dystric Leptic Skeletic Cambisols \\
\hline & 2 & $\begin{array}{l}\text { Dystric Endoskeletic } \\
\text { Amphistagic Cambisols }\end{array}$ & Dystric Endoskeletic Cambisols & $\begin{array}{l}\text { Dystric Cambic Skeletic } \\
\text { Leptosols }\end{array}$ \\
\hline & 3 & $\begin{array}{l}\text { Dystric Skeletic Epistagnic } \\
\text { Cambisols }\end{array}$ & Dystric Skeletic Cambisols & $\begin{array}{l}\text { Dystric Endoskeletic Leptic } \\
\text { Cambisols }\end{array}$ \\
\hline & 4 & Eutric Cambisols & Dystric Endoskeletic Cambisols & Dystric Skeletic Cambisols \\
\hline \multirow{3}{*}{ MNP } & 1 & Eutric Endoskeletic Cambisols & Eutric Skeletic Cambisols & Dystric Skeletic Cambisols \\
\hline & 2 & Dystric Skeletic Cambisols & Dystric Endoskeletic Cambisols & Dystric Cambisols \\
\hline & 3 & Eutric Skeletic Cambisols & Dystric Endoskeletic Cambisols & Eutric Skeletic Cambisols \\
\hline \multirow{3}{*}{ PNP } & 1 & Eutric Endoskeletic Cambisols & Eutric Endoskeletic Cambisols & Eutric Skeletic Cambisols \\
\hline & 2 & Eutric Endoskeletic Cambisols & Eutric Cambic Leptosols & Eutric Endoskeletic Cambisols \\
\hline & 3 & Eutric Cambisols & Endoeutric Cambisols & Endoeutric Cambisols \\
\hline
\end{tabular}
classification (IUSS Working Group WRB 2015).

Notes: BdNP - Bieszczady National Park; MNP - Magura National Park; PNP - Pieniny National Park. 
the individual land use (semi-natural meadow, successional forest and old-growth forest) for both the $0-10 \mathrm{~cm}$ and $10-20 \mathrm{~cm}$ soil layers. An ANOVA Kruskal-Wallis test, at a significance level of $p<0.05$, was used to examine the effect of land use and location on basic soil properties. The contents of carbon humus fractions and calculated coefficients were used to test for significant differences among the different land use variables and soil layers, using an ANOVA Kruskal-Wallis rank test at a significance level $p<0.05$.

Additionally, Principal Component Analysis (PCA) and Redundancy Analysis (RDA), using the Cannoco 5.12 program (Braak \& Smilauer 2012), were performed for selected coefficients and soil properties over the entire $\mathbf{0}-\mathbf{2 0} \mathrm{cm}$ layer. In the PCA diagram, only variables that were significant at $p<0.02$ according to a Monte Carlo permutation test with 499 random permutations (Table 3) were included.

Table 3 Redundancy analysis (RDA) showing the main trends in the data set and indicating the approximate direction of soil variable effects.

\begin{tabular}{l|l|l|c}
\hline Name & Variation explained (\%) & pseudo-F & $p$ \\
\hline C $_{\mathrm{HA}}$ & 49.0 & 26.9 & 0.002 \\
C $_{\mathrm{HA}+\mathrm{FA}}$ & 47.2 & 25.1 & 0.002 \\
\hline $\mathrm{C}_{\mathrm{FA}}$ & 39.4 & 18.2 & 0.002 \\
\hline $\mathrm{Q}_{2 / 3 \_F A}$ & 38.1 & 17.3 & 0.002 \\
\hline $\mathrm{C}_{\text {org }}$ & 38.0 & 17.2 & 0.006 \\
clay & 34.6 & 14.8 & 0.002 \\
\hline $\mathrm{Q}_{4 / 6 \_F A}$ & 26.2 & 10.0 & 0.002 \\
\hline $\mathrm{Q}_{2 / 4 \_F A}$ & 21.8 & 7.8 & 0.012 \\
\hline C:N & 20.6 & 7.3 & 0.012 \\
\hline
\end{tabular}

Notes: Analysis RDA selected only variables that were significant at $p<0.05$ according to a Monte Carlo permutation test with 499 random permutations.

$\mathrm{CHA}_{\mathrm{HA}}$ - carbon of humic acids; $\mathrm{C}_{\mathrm{HA}+\mathrm{FA}}$ - carbon of humic acids and fulvic acids; $\mathrm{C}_{\mathrm{FA}}$ - carbon of fulvic acids; $\mathrm{Q}_{2 / 3}$ FA - quotient of the absorbance measured at 250 $\mathrm{nm}$ and $365 \mathrm{~nm}$ wavelengths measured for fulvic acids; Corg - total organic carbon; $Q_{4 / 6}$ FA- quotient of the absorbance measured at $400 \mathrm{~nm}$ and $600 \mathrm{~nm}$ wavelengths measured for fulvic acids; $\mathrm{Q}_{2 / 4}$ FA quotient of the absorbance measured at $280 \mathrm{~nm}$ and $400 \mathrm{~nm}$ wavelengths measured for fulvic acids; C:N organic carbon and total nitrogen ratio.

\section{Results}

The soils of meadow, successional forest and oldgrowth forest in selected national parks had slightly different properties (Table 4). The highest $\mathrm{C}_{\text {org }}$ content characterized the soils of BdNP. The content of $\mathrm{C}_{\text {org }}$ in
BdNP compared to MNP and PNP in the $0-10 \mathrm{~cm}$ layer were higher, about $36 \mathrm{~g} \mathrm{~kg}^{-1}$ and $29 \mathrm{~g} \mathrm{~kg}^{-1}$ in the meadow, $32 \mathrm{~g} \mathrm{~kg}^{-1}$ and $23 \mathrm{~g} \mathrm{~kg}^{-1}$ in the successional forest and $28 \mathrm{~g} \mathrm{~kg}^{-1}$ and $24 \mathrm{~g} \mathrm{~kg}^{-1}$ in the old-growth forest, respectively. While in the $10-20 \mathrm{~cm}$ the differences between the content of $\mathrm{C}_{\text {org }}$ in BdNP and MNP and PNP were less than $20 \mathrm{~g} \mathrm{~kg}^{-1}$ for all land uses. Overall, the $0-10 \mathrm{~cm}$ layer had higher $\mathrm{C}_{\text {org }}$ compared to the $10-20 \mathrm{~cm}$ layer in all national park soils; however, significant differences only in the successional forest soils were noted (Table 4). The highest content of $\mathrm{N}_{\text {tot }}$ was found in PNP, while significant differences between land uses were not found (Table 4). As also seen in Table 4, the C:N ratio values were significantly highest in BdNP, whereas the mean $\mathrm{pH}_{\mathrm{KCl}}$ ranged from 3.3 in the $0-10 \mathrm{~cm}$ layer of forest in BdNP to 4.5 in the $10-20 \mathrm{~cm}$ layer of forest in PNP and increased from BdNP and MNP to PNP. All of these soil properties depended on localization effects, while the $\mathrm{C}_{\text {org }}$ content depended on localized and land-use effects (Table 4). Overall, soils were classified as loamy (Table 4). Significant differences depended on location were found in the soil texture fractions. The soils of PNP had the lowest content of sand fraction and the highest content of silt fraction while the soils of MNP and PNP characterized higher content of clay fraction compared to the soils of BdNP (Table 4).

The organic carbon fraction composition varied slightly depending on land cover and soil layers (Table 5). In the $0-10 \mathrm{~cm}$ layer, the $\mathrm{C}_{\mathrm{NE}}$ fraction was the dominant fraction, compared to $\mathrm{C}_{\mathrm{HA}}$ by $28 \%, 7 \%$ and $8 \%$ and $\mathrm{C}_{\mathrm{FA}}$ by $12 \%, 3 \%$ and $6 \%$ of all carbon fractions in the semi-natural meadow, successional forest and old-growth forest soils, respectively. While in the $10-20 \mathrm{~cm}$ layer of semi-natural meadow, successional forest and old-growth forest soils the dominant fraction was $\mathrm{C}_{\mathrm{FA}}$, which constituted $11 \%, 20 \%$ and $10 \%$ of the sum of $\mathrm{C}_{\mathrm{HA}+\mathrm{FA}}$ and $\mathrm{C}_{\mathrm{NE}}$, respectively (Table 5). Regarding the land uses in the $0-10 \mathrm{~cm}$ layer, old-growth forest soils had the highest and semi-natural meadow soils the lowest content of

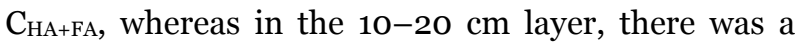
higher content of $\mathrm{C}_{\mathrm{HA}+\mathrm{FA}}$ in old-growth forest soils compared to semi-natural meadow and successional forest soils. The content of $\mathrm{C}_{\mathrm{HA}}$ in the $0-10 \mathrm{~cm}$ layer was higher than in the $10-20 \mathrm{~cm}$ layer, whereas the statistically significant difference was found only for successional forest soil (Table 5). In the $0-10 \mathrm{~cm}$ layer, semi-natural meadow was characterized the lowest 
Table 4 The characterization of soils in the investigated national parks. Mean and standard error values, ANOVA Kruskal-Wallis test results for selected soil properties ( $\mathrm{C}_{\mathrm{org}}, \mathrm{N}_{\text {tot }}, \mathrm{C}: \mathrm{N}, \mathrm{pH}$, soil texture).

\begin{tabular}{|c|c|c|c|c|c|c|c|c|c|}
\hline $\begin{array}{l}\text { Study } \\
\text { site }\end{array}$ & and use & $\begin{array}{l}\text { Layer } \\
(\mathrm{cm})\end{array}$ & $\begin{array}{c}\mathrm{Corg}_{\text {org }} \\
\left(\mathrm{g} \mathrm{kg}^{-1}\right)\end{array}$ & $\begin{array}{c}\mathrm{N}_{\text {tot }} \\
\left(\mathrm{g} \mathrm{kg}^{-1}\right)\end{array}$ & $\mathrm{C}: \mathrm{N}$ & $\mathrm{pH}$ & $\begin{array}{c}\text { Sand } \\
(\%)\end{array}$ & $\begin{array}{l}\text { Silt } \\
(\%)\end{array}$ & $\begin{array}{l}\text { Clay } \\
(\%)\end{array}$ \\
\hline \multirow{6}{*}{ BdNP } & \multirow{2}{*}{ Meadow } & $0-10$ & $57.1 \pm 10.0^{\text {Babc }}$ & $1.7 \pm 0.5^{\mathrm{Aa}}$ & $52.1 \pm 23.6^{\mathrm{Ba}}$ & $3.7 \pm 0.1^{\mathrm{Aa}}$ & $39 \pm 9^{\mathrm{Ba}}$ & $52 \pm 6^{\mathrm{Aa}}$ & $9 \pm 3^{\mathrm{Aa}}$ \\
\hline & & $10-20$ & $27 \cdot 5 \pm 5 \cdot 0^{\mathrm{Bab}}$ & $1.1 \pm 0.1^{\mathrm{Aa}}$ & $26.0 \pm 5.0^{\mathrm{Ba}}$ & $3.9 \pm 0.1^{\mathrm{Aa}}$ & $37 \pm 10^{\mathrm{Ba}}$ & $43 \pm 9^{\mathrm{Aa}}$ & $14 \pm 5^{\mathrm{Aa}}$ \\
\hline & \multirow{2}{*}{ Succession } & $0-10$ & $55.8 \pm 9.6^{\mathrm{Bbc}}$ & $1.7 \pm 0.4^{\mathrm{Aa}}$ & $36.7 \pm 7.7^{\mathrm{Ba}}$ & $3.5 \pm 0.2^{\mathrm{Aa}}$ & $52 \pm 7^{\mathrm{Ba}}$ & $43 \pm 7^{\mathrm{Aa}}$ & $6 \pm 1^{\mathrm{Aa}}$ \\
\hline & & $10-20$ & $26.1 \pm 2.5^{\mathrm{Ba}}$ & $1.0 \pm 0.3^{\mathrm{Aa}}$ & $33.4 \pm 9.7^{\mathrm{Ba}}$ & $3.8 \pm 0.1^{\mathrm{Aa}}$ & $47 \pm 7^{\mathrm{Ba}}$ & $48 \pm 8^{\mathrm{Aa}}$ & $8 \pm 2^{\mathrm{Aa}}$ \\
\hline & \multirow{2}{*}{ Forest } & $0-10$ & $57.2 \pm 6.5^{\mathrm{Bc}}$ & $1.9 \pm 0.4^{\mathrm{Aa}}$ & $33 \cdot 3 \pm 6.4^{\mathrm{Ba}}$ & $3 \cdot 3 \pm 0.1^{\mathrm{Aa}}$ & $58 \pm 6^{\text {Ba }}$ & $37 \pm 6^{\mathrm{Aa}}$ & $6 \pm 1^{\mathrm{Aa}}$ \\
\hline & & $10-20$ & $30.7 \pm 3.4^{\mathrm{Babc}}$ & $1.0 \pm 0.2^{\mathrm{Aa}}$ & $35.1 \pm 10.4^{\mathrm{Ba}}$ & $3.7 \pm 0.1^{\mathrm{Aa}}$ & $55^{ \pm} 8^{\mathrm{Ba}}$ & $38 \pm 6^{\mathrm{Aa}}$ & $6 \pm 2^{\mathrm{Aa}}$ \\
\hline \multirow{6}{*}{ MNP } & \multirow{2}{*}{ Meadow } & $0-10$ & $21.0 \pm 4.0^{\mathrm{Aabc}}$ & $1.5 \pm 0.3^{\mathrm{Aa}}$ & $13.8 \pm 0.6^{\mathrm{Aa}}$ & $3.9 \pm 0.1^{\mathrm{Aa}}$ & $48 \pm 9^{\mathrm{Ba}}$ & $40 \pm 6^{\mathrm{Aa}}$ & $12 \pm 3^{\mathrm{Ba}}$ \\
\hline & & $10-20$ & $12.0 \pm 1.8^{\mathrm{Aab}}$ & $1.4 \pm 0.2^{\mathrm{Aa}}$ & $9.6 \pm 2.5^{\mathrm{Aa}}$ & $3.9 \pm 0.1^{\mathrm{Aa}}$ & $47 \pm 9^{\mathrm{Ba}}$ & $37 \pm 6^{\mathrm{Aa}}$ & $15 \pm 4^{\mathrm{Ba}}$ \\
\hline & \multirow{2}{*}{ Succession } & $0-10$ & $23.8 \pm 2.7^{\mathrm{Abc}}$ & $1.7 \pm 0.1^{\mathrm{Aa}}$ & $13.8 \pm 0.5^{\mathrm{Aa}}$ & $3.5 \pm 0.2^{\mathrm{Aa}}$ & $52 \pm 8^{\mathrm{Ba}}$ & $38 \pm 6^{\text {Аa }}$ & $10 \pm 2^{\mathrm{Ba}}$ \\
\hline & & $10-20$ & $9.9 \pm 0.7^{\mathrm{Aa}}$ & $1.0 \pm 0.1^{\mathrm{Aa}}$ & $9.8 \pm 0.5^{\mathrm{Aa}}$ & $3.6 \pm 0.1^{\mathrm{Aa}}$ & $51 \pm 9^{\mathrm{Ba}}$ & $37 \pm 8^{\mathrm{Aa}}$ & $12 \pm 1^{\mathrm{Ba}}$ \\
\hline & \multirow{2}{*}{ Forest } & $0-10$ & $29.1 \pm 3.3^{\mathrm{Ac}}$ & $1.8 \pm 0.0^{\mathrm{Aa}}$ & $15.9 \pm 1.4^{\mathrm{Aa}}$ & $3.4 \pm 0.0^{\mathrm{Aa}}$ & $32 \pm 3^{\mathrm{Ba}}$ & $53 \pm 1^{\mathrm{Aa}}$ & $15 \pm 2^{\mathrm{Ba}}$ \\
\hline & & $10-20$ & $17.4 \pm 3.6^{\text {Aabc }}$ & $1.3 \pm 0.1 \mathrm{Aa}$ & $13.5^{ \pm 2.9^{\mathrm{Aa}}}$ & $3.5 \pm 0.1^{\mathrm{Aa}}$ & $21 \pm 4^{\mathrm{Ba}}$ & $53 \pm 5^{\mathrm{Aa}}$ & $26 \pm 4^{\mathrm{Ba}}$ \\
\hline \multirow{6}{*}{ PNP } & \multirow{2}{*}{ Meadow } & $0-10$ & $28.1 \pm 3.2^{\mathrm{Aabc}}$ & $3.9 \pm 0.4^{\mathrm{Ba}}$ & $7.2 \pm 0.5^{\mathrm{Aa}}$ & $4.2 \pm 0.3^{\mathrm{Ba}}$ & $22 \pm 5^{\mathrm{Aa}}$ & $56 \pm 8^{\mathrm{Ba}}$ & $22 \pm 4^{\mathrm{Ba}}$ \\
\hline & & $10-20$ & $14.8 \pm 2.0^{\mathrm{Aab}}$ & $2.2 \pm 0.4^{\mathrm{Ba}}$ & $6.7 \pm 0.2^{\mathrm{Aa}}$ & $4.0 \pm 0.1^{\mathrm{Ba}}$ & $15 \pm 1^{\mathrm{Aa}}$ & $52 \pm 4^{\mathrm{Ba}}$ & $33 \pm 3^{\mathrm{Ba}}$ \\
\hline & \multirow{2}{*}{ Succession } & $0-10$ & $32.7 \pm 2.2^{\mathrm{Abc}}$ & $2.2 \pm 0.6^{\mathrm{Ba}}$ & $18.4 \pm 6.7^{\mathrm{Aa}}$ & $4.2 \pm 0.4^{\mathrm{Ba}}$ & $29 \pm 1^{\mathrm{Aa}}$ & $58 \pm 0^{\mathrm{Ba}}$ & $13 \pm 2^{\mathrm{Ba}}$ \\
\hline & & $10-20$ & $13.8 \pm 1.1^{\mathrm{Aa}}$ & $2.1 \pm 0.3^{\mathrm{Ba}}$ & $6.8 \pm 1.1^{\mathrm{Aa}}$ & $4.1 \pm 0.3^{\mathrm{Ba}}$ & $24 \pm 3^{\mathrm{Aa}}$ & $58 \pm 1^{\mathrm{Ba}}$ & $18 \pm 4^{\mathrm{Ba}}$ \\
\hline & \multirow{2}{*}{ Forest } & $0-10$ & $33.1 \pm 4.9^{\mathrm{Ac}}$ & $3.7 \pm 0.3^{\mathrm{Ba}}$ & $8.9 \pm 0.8^{\mathrm{Aa}}$ & $4.4 \pm 0.5^{\mathrm{Ba}}$ & $19 \pm 4^{\mathrm{Aa}}$ & $59 \pm 8^{\mathrm{Ba}}$ & $22 \pm 5^{\mathrm{Ba}}$ \\
\hline & & $10-20$ & $15 \cdot 9 \pm 4 \cdot 7^{\text {Aabc }}$ & $2.4 \pm 0.4^{\mathrm{Ba}}$ & $6.6 \pm 1.1^{\mathrm{Aa}}$ & $4.5 \pm 0.6^{\mathrm{Ba}}$ & $28 \pm 4^{\mathrm{Aa}}$ & $54 \pm 4^{\mathrm{Ba}}$ & $19 \pm 4^{\mathrm{Ba}}$ \\
\hline \multicolumn{10}{|l|}{ Effect: } \\
\hline \multicolumn{3}{|c|}{ Location $(F ; p)$} & $\begin{array}{l}23.76 ; \\
0.00\end{array}$ & $\begin{array}{l}\text { 22.27; } \\
0.00\end{array}$ & $\begin{array}{l}41.67 ; \\
0.00\end{array}$ & $\begin{array}{l}15.28 ; \\
0.00\end{array}$ & $\begin{array}{l}23.84 ; \\
0.00\end{array}$ & $\begin{array}{l}12.91 ; \\
0.00\end{array}$ & $\begin{array}{l}27.63 ; \\
0.00\end{array}$ \\
\hline \multicolumn{3}{|c|}{ Land use $(F ; p)$} & $\begin{array}{l}23.71 \\
0.00\end{array}$ & $\begin{array}{l}9.34 \\
\text { o96 }\end{array}$ & $\begin{array}{l}4.43 \\
0.49\end{array}$ & $\begin{array}{l}9.37 \\
0.09\end{array}$ & $\begin{array}{r}3.34 \\
0.65\end{array}$ & $\begin{array}{l}0.71 \\
0.98\end{array}$ & $\begin{array}{l}6.12 \\
0.29\end{array}$ \\
\hline
\end{tabular}

Notes: BdNP - Bieszczady National Park; MNP - Magura National Park; PNP - Pieniny National Park; Corg - total organic carbon, $\mathrm{N}_{\text {tot }}$ - total nitrogen, $\mathrm{C}: \mathrm{N}$ - organic carbon and total nitrogen ratio. Different capital letters indicate significant differences between national parks and lower case letters indicate significant differences between land use and soil depth variants. Kruskal-Wallis rank test, $p<0.05)$.

Table 5 Mean and standard error values and the ANOVA Kruskal-Wallis rank test results for organic matter fractions $\left(\mathrm{C}_{\mathrm{HA}}+\mathrm{FA}, \mathrm{C}_{\mathrm{HA}}, \mathrm{C}_{\mathrm{FA}}, \mathrm{C}_{\mathrm{NE}}\right.$ and $\left.\mathrm{C}_{\mathrm{HA}}: \mathrm{C}_{\mathrm{FA}}\right)$ in different soil layers of semi-natural meadow, natural successional forest and old-growth forest.

\begin{tabular}{|c|c|c|c|c|c|c|}
\hline Layer (cm) & Land use & $\mathrm{C}_{\mathrm{HA}+\mathrm{FA}}\left(\mathrm{g} \mathrm{kg}^{-1}\right)$ & $\mathrm{C}_{\mathrm{HA}}\left(\mathrm{g} \mathrm{kg}^{-1}\right)$ & $\mathrm{C}_{\mathrm{FA}}\left(\mathrm{g} \mathrm{kg}^{-1}\right)$ & $\mathrm{C}_{\mathrm{NE}}\left(\mathrm{g} \mathrm{kg}^{-1}\right)$ & $\mathrm{C}_{\mathrm{HA}}: \mathrm{C}_{\mathrm{FA}}$ \\
\hline \multirow{3}{*}{$0-10$} & Meadow & $21.3 \pm 3.4^{\mathrm{a}}$ & $6.5^{ \pm 1.8^{\mathrm{ab}}}$ & $12.0 \pm 1.7^{\mathrm{a}}$ & $16.3 \pm 5.7^{\mathrm{a}}$ & $0.8 \pm 0.1^{\mathrm{a}}$ \\
\hline & Succession & $24.9 \pm 3.8^{a}$ & $11.8 \pm 1.9^{b}$ & $13.1 \pm 2.0^{\mathrm{a}}$ & $14.4 \pm 2.5^{\mathrm{a}}$ & $0.9 \pm 0.1^{\mathrm{a}}$ \\
\hline & Forest & $25 \cdot 7 \pm 3 \cdot 5^{\mathrm{a}}$ & $12.4 \pm 2.1^{\mathrm{b}}$ & $13 \cdot 3 \pm 1.5^{\mathrm{a}}$ & $15.8 \pm 3.7^{\mathrm{a}}$ & $0.9 \pm 0.1^{\mathrm{a}}$ \\
\hline \multirow{3}{*}{$10-20$} & Meadow & $12.9 \pm 2.3^{\mathrm{a}}$ & $4.6 \pm 1.0^{\mathrm{a}}$ & $8.2 \pm 1.5^{\mathrm{a}}$ & $6.2 \pm 1.0^{\mathrm{a}}$ & $0.6 \pm 0.1^{\mathrm{a}}$ \\
\hline & Succession & $12.5^{ \pm 2.2^{\mathrm{a}}}$ & $3.9 \pm 0.8^{a}$ & $8.6 \pm 1.6^{a}$ & $5.1 \pm 1.0^{\mathrm{a}}$ & $0.5^{ \pm 0.1^{\mathrm{a}}}$ \\
\hline & Forest & $14.9 \pm 2.1^{\mathrm{a}}$ & $5.2 \pm 0.8^{\mathrm{ab}}$ & $9.6 \pm 1.4^{a}$ & $7.4 \pm 2.0^{\mathrm{a}}$ & $0.6 \pm 0.1^{a}$ \\
\hline
\end{tabular}

Notes: $\mathrm{C}_{\mathrm{HA}+\mathrm{FA}}-$ carbon of humic acids and fulvic acids; $\mathrm{C}_{\mathrm{HA}}-$ carbon of humic acids; $\mathrm{C}_{\mathrm{FA}}-$ carbon of fulvic acids, $\mathrm{C}_{\mathrm{NE}}$ - non-extractable carbon. Different lower case letters indicate significant differences between land use and soil depth variants (ANOVA, Kruskal-Wallis rank test, $p<0.05$ ).

$\mathrm{C}_{\mathrm{HA}}: \mathrm{C}_{\mathrm{FA}}$ ratio, while in the $10-20 \mathrm{~cm}$ layer the lowest $\mathrm{C}_{\mathrm{HA}}: \mathrm{C}_{\mathrm{FA}}$ in the successional forest soil was found (Table 5).

The $Q_{4 / 6}$ coefficient values calculated for humic acids and fulvic acids were higher in the $0-10 \mathrm{~cm}$ than those in the $10-20 \mathrm{~cm}$ layer for each examined land use variable (Table 6). In the $0-10 \mathrm{~cm}$ layer, the lowest $\mathrm{Q}_{4 / 6}$ value for humic acids was observed in the seminatural meadow and the highest in the succession forest, while in the $10-20 \mathrm{~cm}$ layer the lowest $Q_{4 / 6}$ value for humic acids in the successional forest and the highest in the old-growth forest were noted. However, the $Q_{4 / 6}$ coefficient values for fulvic acids were the lowest in the semi-natural meadow in both examined layers (Table 6). The $Q_{2 / 4}$ coefficient calculated for humic acids had the highest values in the semi-natural meadow soils for both $0-10 \mathrm{~cm}$ and $10-20 \mathrm{~cm}$ layers. Alike, the calculated coefficient $Q_{2 / 4}$ for fulvic acids was higher in the semi-natural meadow soils compared to successional forest and old-growth forest soils in both examined layers. In the $0-10 \mathrm{~cm}$ layer, the seminatural meadow soils characterized the highest $Q_{2 / 3}$ 
Table 6 Mean and standard error values and the Kruskal-Wallis rank test results for absorbance coefficients $\left(Q_{4 / 6}\right.$, $\mathrm{Q}_{2 / 4}, \mathrm{Q}_{2 / 3}$ and $\Delta \log \mathrm{K}$ ) in humic and fulvic acids in soil layers of semi-natural meadow, natural successional forest and old-growth forest.

\begin{tabular}{|c|c|c|c|c|c|}
\hline \multirow{2}{*}{ Layer $(\mathrm{cm})$} & \multirow{2}{*}{ Land use } & \multicolumn{4}{|c|}{ Humic acids } \\
\hline & & $\mathrm{Q}_{4 / 6}$ & $\mathrm{Q}_{2 / 4}$ & $\mathrm{Q}_{2 / 3}$ & $\Delta \log \mathrm{K}$ \\
\hline \multirow{3}{*}{$0-10$} & Meadow & $3.8 \pm 0.3^{b c}$ & $3.8 \pm 0.1^{\mathrm{c}}$ & $2.8 \pm 0.1^{\mathrm{ab}}$ & $0.6 \pm 0.0^{\mathrm{ab}}$ \\
\hline & Succession & $4.3 \pm 0.2^{c}$ & $3.7 \pm 0.0^{c}$ & $2.9 \pm 0,0^{b}$ & $0.6 \pm 0.0^{b}$ \\
\hline & Forest & $4.1 \pm 0.1^{c}$ & $3.6 \pm 0.1^{b c}$ & $2.9 \pm 0.0^{b}$ & $0.6 \pm 0.0^{b}$ \\
\hline \multirow{3}{*}{$10-20$} & Meadow & $2.4 \pm 0.4^{\mathrm{ab}}$ & $3.4 \pm 0.1^{\mathrm{abc}}$ & $2.5 \pm 0.2^{\mathrm{ab}}$ & $0.5^{ \pm 0.1^{\mathrm{ab}}}$ \\
\hline & Succession & $2.0 \pm 0.3^{\mathrm{a}}$ & $2.7 \pm 0.2^{\mathrm{a}}$ & $2.2 \pm 0.2^{\mathrm{a}}$ & $0.4 \pm 0.0^{\mathrm{a}}$ \\
\hline & Forest & $2.6 \pm 0.2^{\mathrm{ab}}$ & $3.0 \pm 0.1^{\mathrm{ab}}$ & $2.6 \pm 0.1^{\mathrm{a}}$ & $0.4 \pm 0.0^{\mathrm{a}}$ \\
\hline \multirow{2}{*}{ Layer $(\mathrm{cm})$} & Land use & \multicolumn{4}{|c|}{ Fulvic acids } \\
\hline & & $\mathrm{Q}_{4 / 6}$ & $\mathrm{Q}_{2 / 4}$ & $\mathrm{Q}_{2 / 3}$ & $\Delta \log \mathrm{K}$ \\
\hline \multirow{3}{*}{$0-10$} & Meadow & $3.5^{ \pm 0.6^{\mathrm{ab}}}$ & $21.1 \pm 2.7^{\mathrm{ab}}$ & $7.4 \pm 0.2^{\mathrm{abc}}$ & $0.6 \pm 0.1^{\mathrm{a}}$ \\
\hline & Succession & $5.1 \pm 0.5^{\mathrm{b}}$ & $14.1 \pm 0.9^{a}$ & $6.6 \pm 0.1^{\mathrm{a}}$ & $0.7 \pm 0.0^{\mathrm{a}}$ \\
\hline & Forest & $4.7 \pm 0.2^{b}$ & $14.4 \pm 0.9^{\mathrm{ab}}$ & $6.7 \pm 0.3^{\mathrm{ab}}$ & $0.7 \pm 0.0^{a}$ \\
\hline \multirow{3}{*}{$10-20$} & Meadow & $2.2 \pm 0.4^{\mathrm{a}}$ & $23.2 \pm 3 \cdot 3^{\mathrm{b}}$ & $9.2 \pm 0.5^{c}$ & $1.0 \pm 0.3^{\mathrm{a}}$ \\
\hline & Succession & $3.1 \pm 0.9^{\mathrm{ab}}$ & $21.5 \pm 1.9^{\mathrm{ab}}$ & $8.8 \pm 0.4^{c}$ & $0.9 \pm 0.2^{\mathrm{a}}$ \\
\hline & Forest & $3.6 \pm 0.7^{\mathrm{ab}}$ & $16.7 \pm 0.8^{\mathrm{ab}}$ & $8.0 \pm 0.4^{b c}$ & $0.6 \pm 0.1^{\mathrm{a}}$ \\
\hline
\end{tabular}

Notes: $\mathrm{Q}_{4 / 6}$ - quotient of the absorbance measured at $400 \mathrm{~nm}$ and $600 \mathrm{~nm}$ wavelengths; $\mathrm{Q}_{2 / 4}$ - quotient of the absorbance measured at $280 \mathrm{~nm}$ and $400 \mathrm{~nm}$ wavelengths; $\mathrm{Q}_{2 / 3}-$ quotient of the absorbance measured at $250 \mathrm{~nm}$ and $365 \mathrm{~nm}$ wavelengths; $\Delta \log \mathrm{K}=\log \mathrm{K}_{400}-\log \mathrm{K}_{600}$, where $\mathrm{K}$ is a absorbance values measured at $400 \mathrm{~nm}$ and 600 $\mathrm{nm}$ wavelengths. Different lower case letters indicate significant differences between land use and soil depth variants (ANOVA, Kruskal-Wallis rank test, $p<0.05$ ).

Table 7 Minimum and maximum of colour value and chroma, Munsell chart colours, mean and standard error values of A Horizon Development Index (ADI).

\begin{tabular}{|c|c|c|c|c|c|c|c|c|c|c|c|c|c|}
\hline \multirow{3}{*}{$\begin{array}{l}\text { Layer } \\
(\mathrm{cm})\end{array}$} & \multirow{3}{*}{ Land use } & \multicolumn{6}{|c|}{ Dry } & \multicolumn{6}{|c|}{ Wet } \\
\hline & & \multicolumn{2}{|c|}{ Value } & \multicolumn{2}{|c|}{ Chroma } & \multirow{2}{*}{$\begin{array}{c}\text { Munsell } \\
\text { chart }\end{array}$} & \multirow{2}{*}{$\mathrm{ADI}$} & \multicolumn{2}{|c|}{ Value } & \multicolumn{2}{|c|}{ Chroma } & \multirow{2}{*}{$\begin{array}{c}\text { Munsell } \\
\text { chart }\end{array}$} & \multirow{2}{*}{$\mathrm{ADI}$} \\
\hline & & $\min$ & $\max$ & $\min$ & $\max$ & & & $\min$ & $\max$ & $\min$ & $\max$ & & \\
\hline \multirow{3}{*}{$0-10$} & Meadow & 4 & 7 & 2 & 4 & & $0.5^{ \pm 0.2^{\mathrm{abc}}}$ & 2 & 5 & 3 & 6 & & $0.7 \pm 0.3^{\mathrm{ab}}$ \\
\hline & Succession & 3 & 6 & 2 & 3 & & $0.8 \pm 0.4^{b c}$ & 2 & 4 & 1 & 4 & & $1.3^{ \pm 0.8^{b}}$ \\
\hline & Forest & 2 & 6 & 1 & 4 & & $1.1 \pm 0.7^{\mathrm{c}}$ & 1.7 & 4 & 1 & 4 & & $1.9 \pm 1.0^{b}$ \\
\hline \multirow{3}{*}{$10-20$} & Meadow & 5 & 7 & 2 & 4 & & $0.5^{ \pm 0.1^{\mathrm{ab}}}$ & 4 & 5 & 2 & 8 & & $0.6 \pm 0.3^{\mathrm{a}}$ \\
\hline & Succession & 5 & 7 & 3 & 4 & & $0.4 \pm 0.1^{\mathrm{a}}$ & 3 & 5 & 3 & 6 & & $0.5^{ \pm 0.2^{\mathrm{a}}}$ \\
\hline & Forest & 4 & 7 & 3 & 6 & & $0.5 \pm 0.1^{a b c}$ & 2 & 5 & 2 & 8 & & $0.9 \pm 0.4^{\mathrm{ab}}$ \\
\hline
\end{tabular}

Notes: All of the examined soil samples were characterized by a 10YR Munsell hue. Different lower case letters indicate significant differences between land use and soil depth variants (ANOVA, Kruskal-Wallis rank test, $p<0.05$ ).

coefficient values calculated for fulvic acids compared to successional forest and old-growth forest soils, while in the 10-20 cm layer the lowest $\mathrm{Q}_{2 / 3}$ in the oldgrowth forest soils was noted. However, the $\mathrm{Q}_{2 / 3}$ values calculated for humic acids were similar between all examined land use variants in both soil layers (Table 6). The $Q_{2 / 3}$ values calculated for fulvic acids in the 10$20 \mathrm{~cm}$ layer decrease from semi-natural meadow via successional forest to old-growth forest. However, no statistically significant differences between seminatural meadow, successional forest and old-growth forest soils in the individual layers for humic and fulvic acids were found for the $\Delta \log \mathrm{K}$ values (Table 6).

The colour of examined soils was different between semi-natural meadow, successional forest and old-growth forest, especially in the $0-10 \mathrm{~cm}$ soil layer. All of the examined soil samples were characterized by a 10YR Munsell hue; however, the soil colour darkened from semi-natural meadow via successional forest to old-growth forest (Table 7). The calculated ADI mean values of examined different land use soils varied, ranging from 0.4 to 1.1 and from 0.5 to 1.9 in dry and wet soil samples, respectively (Table 7). The $\mathrm{ADI}_{\text {dry }}$ and $\mathrm{ADI}_{\text {wet }}$ mean values increased significantly from semi-natural meadow to old-growth forest in the $0-10 \mathrm{~cm}$ layer. Whereas, in the $10-20 \mathrm{~cm}$ layer, the lowest mean $\mathrm{ADI}_{\text {wet }}$ and $\mathrm{ADI}_{\text {dry }}$ values were found in the successional forest and the highest were observed in the old-growth forest soils.

The score plot in two principal components represents $80.9 \%$ of the total variability. The first PCA axis explains $70.8 \%$ and was strongly correlated with a few original variables, positively with clay content 
and negatively with $\mathrm{ADI}$ and content of humic substances ( $\mathrm{C}_{\mathrm{HA}}, \mathrm{C}_{\mathrm{FA}}$ and $\mathrm{C}_{\mathrm{HA}+\mathrm{FA}}$ ). The second PCA axis explains only $10.1 \%$ and is weakly connected with C:N ratio, $Q_{2 / 3}$ and $Q_{4 / 6}$ coefficients determined for fulvic acids (Fig. 1). A positive correlation between $\mathrm{C}_{\text {org }}, \mathrm{C}_{\mathrm{FA}}$, $\mathrm{C}_{\mathrm{HA}}$, and $\mathrm{ADI}_{\text {dry }}$ as well as $\mathrm{ADI}_{\text {wet }}$ was noted (Fig. 1). The $\mathrm{ADI}_{\text {dry }}$ and $\mathrm{ADI}_{\text {wet }}$ values were positively correlated with $Q_{4 / 6}$ determined for fulvic acids. However, a negative correlation between $\mathrm{ADI}_{\text {dry }}$ and $\mathrm{ADI}_{\text {wet }}$ and $Q_{2 / 4}$ as well as $Q_{2 / 3}$ for fulvic acids was noted (Fig. 1).

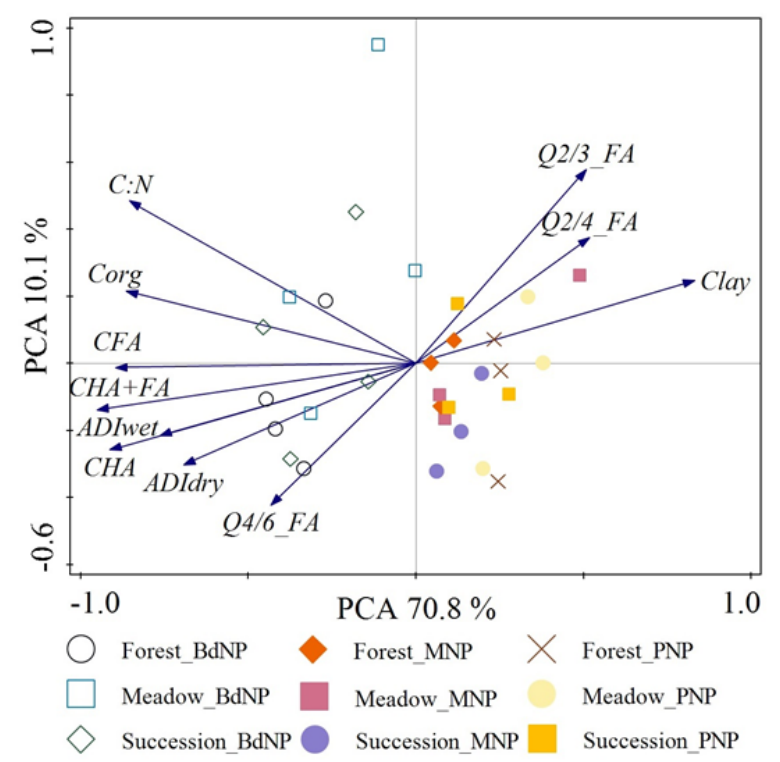

Fig. 1 Principal Component Analysis (PCA) for selected coefficients (ADI wet, $_{\text {ADI }}$ dry $, Q_{4 / 6}, Q_{2 / 4}, Q_{2 / 3}$ ) and soil properties (C:N, $\mathrm{C}_{\mathrm{org}}, \mathrm{C}_{\mathrm{FA}}, \mathrm{C}_{\mathrm{HA}}, \mathrm{C}_{\mathrm{HA}+\mathrm{FA}}$, clay) over the entire $0-20 \mathrm{~cm}$ layer.

Notes: BdNP - Bieszczady National Park; MNP Magura National Park; PNP - Pieniny National Park; $\mathrm{ADI}_{\text {wet }}$ - A Horizon Development Index measured in wet soil samples; $\mathrm{ADI}_{\text {dry }}$ - A Horizon Development Index measured in dry soil samples; $Q_{4 / 6}$ FA- quotient of the absorbance measured at $400 \mathrm{~nm}$ and $600 \mathrm{~nm}$ wavelengths measured for fulvic acids; $\mathrm{Q}_{2 / 4} \_\mathrm{FA}$ quotient of the absorbance measured at $280 \mathrm{~nm}$ and $400 \mathrm{~nm}$ wavelengths measured for fulvic acids; $\mathrm{Q}_{2 / 3}$ FA - quotient of the absorbance measured at $250 \mathrm{~nm}$ and $365 \mathrm{~nm}$ wavelengths measured for fulvic acids; Corg organic carbon; C:N - organic carbon and total nitrogen ratio; $\mathrm{C}_{\mathrm{HA}+\mathrm{FA}}-$ carbon of humic acids and fulvic acids; $\mathrm{C}_{\mathrm{HA}}$ - carbon of humic acids: $\mathrm{C}_{\mathrm{FA}}-$ carbon of fulvic

\section{Discussion}

The study covered three Polish national parks of the Carpathian Mountains, whose soils varied in their properties. The differences in their soil properties may reflect the location of the individual national parks. The significantly highest content of Corg in soils of BdNP could be related to the higher altitude compared to MNP and PNP. One of the main environmental factor influencing soil nutrient distribution on a small scale is topography; Martin et al. (2010), for instance, highlighted a meaningful role of topography in soil carbon accumulation. Additionally, a certain amount of moisture is essential for the decomposition of organic residues and as a result increase carbon content in soil (Martin et al. 2010). However, geographic location, climate, precipitation, and microtopography can lead to different outcomes (Jiang et al. 2019). For example in Himalayan soil, C:N ratio was found to decrease with increasing elevation (Müller et al. 2017); conversely in the Polish Carpathians, C:N increased with increasing altitude above sea level. Also, similar results have been found in subtropical regions in China (He et al. 2016).

However, soil texture was the factor that influenced $\mathrm{N}_{\text {tot }}$ content in studied soils the most. In soils of the PNP, the highest content of $\mathrm{N}_{\text {tot }}$ as well as the highest silt and clay fraction were observed. Gami et al. (2009) stated that silt+clay content significantly explained the variation of total nitrogen content in forest and cultivated soils. Moreover, higher $\mathrm{pH}$ values in the soils of PNP compared to BdNP and MNP may reflect different parent materials. According to Niemyska-Łukaszuk et al. (2002), the parent materials for eutric cambisols in PNP are especially rocks of sandstone-shale series with an admixture of carbonate binder, which influences higher $\mathrm{pH}$ values, whilst the BdNP and MNP soils were formed on the Carpathian Flysch, where the dominant rocks are sandstones, mudstones and shales (Skiba 1999; Skiba and Drewnik 2000). Despite the differences in the basic properties of soil located in different parts of the Carpathians, the broad research area contributed to the generalization of the changes in $\mathrm{OM}$ decomposition and humification caused by natural forest succession in this region.

\subsection{Soil colour and the A Horizon Development Index (ADI)}

As expected, the old-growth forest soils were characterized by the darkest soil colour, and the meadow the lightest, which is related to the content of $\mathrm{C}_{\text {org }}$ as well as the content of humic substances. So far, 
soil colour has been used mainly as an indicator of organic carbon content in soils (Konen et al. 2003; Wills et al. 2007). Mazurek et al. (2016), based on soil colour features, calculated the ADI to determine the degree of stabilization of the OM in the studied profile. The results from our study confirm the relationship between increasing ADI value and content of $\mathrm{C}_{\text {org }}$, by the positive correlation between the $\mathrm{ADI}_{\text {wet }}$ and ADIdry and $\mathrm{C}_{\text {org }}$ as well as carbon content of humic substance fractions, which are a meaningful part of organic carbon in the soil. The correlation results confirmed that calculating ADI value may be a simple and timesaving way to indicate changes in $\mathrm{C}_{\text {org }}$ and humic substance content in soils during natural forest succession. The colour of humic substances may be yellowish-brown to black depending on the degree of decay and concentration. It is well known that humic substances contribute to the black colour of soils by accumulation in the surface horizon of the soil (Weber 2020). Nevertheless, sometimes the darkness of soil is not related to the content of organic carbon and may be caused by the presence in the soil of additional compounds such as melanin pigments found in many fungi and some bacteria (Guggenberger 2005) which are black and brown coloured and are assumed to represent precursors of humic substances in soil (Saiz-Jimenez 1996). But, so far there is little information about such interferences in soil colour; however, the relationships between soil colour and content of organic carbon were more often subject of studies.

\subsection{Composition of humic substances}

Humic substances are the most widespread naturally occurring organic substances, which have attracted the interest of many scientists (Weber et al. 2018). The relationship between different components of humic substances is still of great interest in terms of studying the effect of land use and soil management on soil quality (Reddy et al. 2012; Zhiyanski et al. 2017). Humins are the most dominant fraction of humic substances in soils, independent of land use (Guimarães et al. 2013). This was also observed in this study in the $0-10 \mathrm{~cm}$ layer, where $\mathrm{C}_{\mathrm{NE}}$ was the dominant fraction in all examined land use variants. However, in the $10-20 \mathrm{~cm}$ layer, the fractional composition took a slightly different shape, with the dominance of $\mathrm{C}_{\mathrm{FA}}$. Such a composition in the individual layers may be related to the insolubility of humins and the high solubility of fulvic acids under both alkaline and acid conditions (Sutton and Sposito
2005). Simultaneously, the higher content of $\mathrm{C}_{\mathrm{FA}}$ compared to $\mathrm{C}_{\mathrm{HA}}$ in both examined layers and all land use variants indicate high mobility of the OM. Also, Guimarães et al. (2013) have shown a higher content of fulvic acids than humic acids in different agriculture areas, and they stated that the predominance of fulvic acids in organic carbon composition indicated a slow rate of SOM decomposition or frequent inputs of fresh residues. Such a distribution of humic and fulvic acids was observed in forest soils (Guggenberger and Zech 1994; Schnitzer 1999). Moreover, Giurov and Artinova (2001) found the humus in Cambisols as a fulvichumic type, which confirmed that the dominance of $\mathrm{C}_{\mathrm{FA}}$ and $\mathrm{C}_{\mathrm{NE}}$ fractions is common in that soil type. Despite the fact that humic acids bind strongly to soils and are resistant to microbial metabolism, they are depleted from soils by wind and water erosion as well as by water leaching (Susic 2016).

The significantly higher $\mathrm{C}_{\mathrm{HA}}$ content in the $0-10$ $\mathrm{cm}$ layer compared to the $10-20 \mathrm{~cm}$ layer may be caused by the continuous input of fresh organic matter on the soil surfaces as well as greater microbial activity in the top layer of soil, which are the main factors affecting humification (Li et al. 2015). Conversely, despite the higher input of $\mathrm{OM}, \mathrm{C}_{\mathrm{org}}$ and $\mathrm{C}_{\mathrm{HA}}$ content in the $0-10 \mathrm{~cm}$ layers compared to the $10-20 \mathrm{~cm}$ layers, the calculated coefficients such as $Q_{4 / 6}, Q_{2 / 4}$ and $\Delta \log$ $\mathrm{K}$ for humic acids and fulvic acids have shown a lower advancement of the humification process in the top layer. Such inaccuracies might be caused by climatic conditions, which are factors influencing SOM humification and carbon accumulation (Wang et al. 2016b). Wang et al. (2016a) found a decrease in soil aromaticity with increasing elevation. Moreover, Drewnik (2000) stated that the rate of OM decomposition in the Carpathians decreased with increasing altitude, which could be related to lower temperatures. The lower temperature can result in an increase in the recalcitrant SOM due to restriction of microbial decomposition (Wang et al. 2016a).

\subsection{Advanced organic matter humification}

It is well known that humification and mineralization are parallel processes in the soil environment. According to Kandeler et al. (2005), the decomposition of organic material is dynamic, and a stepwise process results in a small portion converting to complex and more stable material; however, readily available litter and plant exudates are transformed and 
nutrients are mineralized mainly via respiratory processes of the microbiota. Many authors (Cerli et al. 2008; Quideau et al. 2000) have highlighted the important role of the humic substances' age in terms of the degree of transformations in their functional groups, which in our study was confirmed by an increased advancement of the humification process with soil depth.

The calculated absorbance coefficients contributed to characterizing the differences in the soils from different land uses. Based on the $Q_{4 / 6}$ ratio, which is often used to characterize humic substances and is considered as an indicator of the degree of maturity (Vázquez et al. 2016) as well as reflecting the degree of condensation and aromatic structures (Aranda et al. 2011), we observed a significant decrease in maturity and condensation degree of fulvic acids in the $0-10 \mathrm{~cm}$ soil layer from meadow to successional forest soils (i.e. an increase in $Q_{4 / 6}$ ). It is commonly assumed that a high degree of condensation and aromaticity of humic substances are indicators of a highly advanced humification process. The high humification in meadow soils was also noted by Ukalska-Jaruga et al. (2019), who confirmed that in grassland soils humified OM is very well protected against mineralization.

Inversely, in accordance with the $Q_{2 / 3}$ coefficient reflecting the degree of structural degradation of humic substances' components (Suhett et al. 2004), a significantly lower degradation of fulvic acids structures (a decrease in $Q_{2 / 3}$ ) in successional forest compared to the semi-natural meadow was noted. The differentiation between examined land uses may be affected by microbial activity, which influences the timing of active plant residue transformation in soils (Li et al. 2015). More stable fulvic acids structures in successional forest soils may be the result of the landuse history, however. Kalbitz et al. (2000) noted the impact of long-term agricultural use and high input on increasing aromatic structures and further humification of fulvic acids. Moreover, Dean et al. (2020) noticed the influence of historical human activity on relocated carbon from primary forests. Such processes may account for the presence of old fulvic acids from decomposed coarse lateral roots of old trees in meadow soils that initially were covered by forests. Wilson et al. (1997) observed a legacy of SOC heterogeneity in one or two successional generations of forests; however, the pattern was not clear for examined different surfaces. According to
Oyarzún et al. (2011), the SOC legacy is less in secondary forests and could reduce soil variability.

The $\mathrm{Q}_{2 / 4}$ coefficient characterizes the advance of OM humification (Ammari et al. 2012) as well as reflects the contents of organic materials at the beginning of transformation (Guangyin \& Youcai 2017), and here indicated the decrease in the content of humic substances in the initial stage of decomposition from semi-natural meadow to successional forest. These results may indicate that in the $\mathbf{0}-10 \mathrm{~cm}$ layer of seminatural meadow highly and lightly decomposed OM occur at the same time while in old-growth forest and successional forest, lightly decomposed material is predominant. These differences may be influenced by the varied susceptibility to the decomposition of meadow vegetation compared to litterfall from deciduous trees. Forest litter decomposition often is divided into three stages, the early stage and the late stage with the dominance of non-lignified and lignified tissue decomposition, respectively, and the final stage (Berg 2018). Similarly, in the 10-20 cm layer, the lower decomposed organic material and higher content of fulvic and humic acids at the beginning of the transformation in semi-natural meadows (as expressed by higher values of $Q_{2 / 4}$ ) were noted. It could be caused by higher input of plant residues compared to oldgrowth forest and successional forest, particularly from dense root systems. Gill and Jackson (2000) have found significant differences in root turnover among varied vegetation types; tree roots had the slowest turnover rate and grasslands the fastest. Schmidt et al. (2011) indicated that root-derived carbon is retained in soils much more efficiently than aboveground inputs of plant litter. Additionally, decreasing the $Q_{2 / 4}$ values from semi-natural meadow to successional forest and old-growth forest indicates a higher degree of humification advancement in tree ecosystems. It is very well known that long-term SOM accumulation takes place in the humus layer of forest soils. The meaningful role of an established forest ecosystem in carbon sequestration is highlighted in the literature; for example, Ni et al. (2016) have shown the importance of continuity of alpine forests in the accumulation of SOM and carbon sequestration.

\subsection{A Horizon Development Index and UV-VIS spectroscopic coefficients}

The positive correlation between the $\mathrm{Q}_{4 / 6}$ calculated for fulvic acids, which determines the 
advancement of the humification process and ADIs values suggests that these indexes are inconsistent. The interpretation of the spectroscopic results was based on a long-term study on the absorbance features of humic substances (Chen et al. 1977; Gonet and Dębska 1998; Kononowa 1968; Kumada 1987; Schnitzer and Khan 1972). Despite the finding that the humification process increased aromatically of humic substances, some authors (Baldock et al. 1992; Kögel-Knabner 1997; Quideau et al. 2000) have shown that an increase in the degree of humic substance humification is accompanied by an increase in the degree of their aliphaticity.

Moreover, the direction of humic substance transformation is related to the oxygen conditions in the soil. According to Thomsen et al. (2008), aerobic conditions favour an increase in aromaticity, while anaerobic conditions favour an increase in aliphaticity of humic substances along the humification process. Thus, the increase of humic substance aromaticity is not always equivalent to the progress of the humification process. However, in this study the presence of fulvic acids at the beginning of the transformation process in the examined semi-natural meadow soils provided lower ADI values. Thus, the more advanced the fulvic acid humification and the higher the size of fulvic acids structures, the higher the ADI values, which is expressed in the negative correlation between ADI values and $\mathrm{Q}_{2 / 4}$ as well as $\mathrm{Q}_{2 / 3}$. In the opposite sense, the occurrence of lowersize humic acids structures increases ADI values and results in darker soils.

Recent research (Christl et al. 2008) has shown that the smaller humic acids may have a more compact structure, caused by their larger content of aromatic carbon and a higher degree of condensation. Christl et al. (2008) also stated that small, uniform molecules are not the primary building blocks of humic acids with high apparent molecular weights. In fact, they found clear chemical differences between the molecular size classes of soil humic acids. Unfortunately, the chemical structure of humic substances is difficult to uniquely define because of a large number of chemical units in the compounds as well as changes in the percentage contribution of chemical units in humic substances molecules depending on habitat and bioecological conditions (Mielnik 2016). Despite the obvious role of the presence of $\mathrm{OM}$ in soil on colour, the present study has shown that the degree of degradation of humic substances structures (expressed by $\mathrm{Q}_{2 / 3}$ ) is a meaningful factor influencing soil colour and soil development degree.

Comparing both methods used here, UV-VIS spectroscopy is useful in determining the absorbance of aromatic systems, which is related to the degree of humic substances' humification as well as the quality of soil (Da Silva et al. 2018), whereas the ADI showed the diversity of the degree of organic matter stabilization. The ADI correlated with organic carbon content and is especially dependent on soil colour and the amount of material scattered as well as its exposure time (Mazurek et al. 2016). Thus, each of the presented methods investigating the advancement of organic material decomposition and development of uppermost soil layers is focused on different features of the soil. The calculation of ADI focuses only on physical soil properties, while calculating the absorbance coefficients is based on spectroscopic analysis penetrating the chemical structure of organic matter.

\section{Conclusions}

The natural forest succession in the Polish Carpathians influenced soil colour darkening and shaped the development of the uppermost $(0-20 \mathrm{~cm})$ soil layer, as expressed by the calculated ADI. Moreover, spectroscopic analyses of humic substances showed that land-use changes impacted the advancement of the humification process. Nevertheless, these changes were also related to the soil depth. In the $0-10 \mathrm{~cm}$ soil layer, the natural forest succession reduced the rate of the humification process as well as decreasing the degree of maturity of fulvic acids. Conversely, in the $10-20 \mathrm{~cm}$ soil layer, changing the land use from semi-natural meadow via successional forest to an old-growth forest led to an increase in the rate of the humification process as well as a decrease in the content of both humic and fulvic acids at the beginning of the transformation.

The comparison of the ADI results and the calculated spectroscopic coefficients indicates that these indices are based on different features of soils and cannot be used interchangeably as indicators of the development of soil. Moreover, the degree of advance of the humification process is related mainly to features of the individual humic substances.

Therefore, there is a need to extend studies of humic substances. It is especially worth focusing on the 
structure of individual humic substances and the presence of different functional groups, which was missing in the present study. Moreover, future research could divide the successional stages according to the age of the trees to capture and better understand the ratio and direction of $\mathrm{OM}$ decomposition in soils during natural forest succession.

\section{Acknowledgments}

This study was supported by Statutory financial support of Ministry of Science and Higher Education RP Department of Soil Science and Agrophysics [010013Do11 in 2021] University of Agriculture in Krakow. We wish to thank Cambridge Proofreading team for reading the manuscript and for language corrections.

Electronic supplementary material: Supplementary material (Appendixes 1-2) is available in the online version of this article at https://doi.org/10.1007/s11629-021-6836-x

\section{References}

Aitkenhead MJ, Coull M, Towers W, et al (2013) Prediction of soil characteristics and colour using data from the National Soils Inventory of Scotland. Geoderma 200-201:99-107. https://doi.org/10.1016/j.geoderma.2013.02.013

Ammari TG, Al-Omari Q, Abbassi BE (2012) Composting sewage sludge amended with different sawdust proportions and textures and organic waste of food industry - Assessment of quality. Environ Technol (United Kingdom) 33:1641-1649. https://doi.org/10.1080/09593330.2011.641589

Aranda V, Ayora-Cañada MJ, Domínguez-Vidal A, et al (2011) Effect of soil type and management (organic vs. conventional) on soil organic matter quality in olive groves in a semi-arid environment in Sierra Mágina Natural Park (S Spain). Geoderma 164:54-63. https://doi.org/10.1016/j.geoderma.2011.05.010

Baldock JA, Oades JM, Waters AG, et al (1992) Aspects of the chemical structure of soil organic materials as revealed by solidstate13C NMR spectroscopy. Biogeochemistry 16:1-42. https://doi.org/10.1007/BFo2402261

Berg B (2018) Decomposing litter; limit values; humus accumulation, locally and regionally. Appl Soil Ecol 123:494508. https://doi.org/10.1016/j.apsoil.2017.06.026

Braak CJF ter, Smilauer P (2012) Canoco reference manual and user's guide: software for ordination, version 5.0

Buol S, Southard R, Graham R, et al. (2003) Soil Genesis and Classification, fifth. Press Ames, Iowa State, USA.

Cerli C, Celi L, Kaiser K, et al. (2008) Changes in humic substances along an age sequence of Norway spruce stands planted on former agricultural land. Org Geochem 39:12691280. https://doi.org/10.1016/j.orggeochem.2008.06.001

Chen Y, Senesi N, Schnitzer M (1977) Information Provided on Humic Substances by E4/E6 Ratios. Soil Sci Soc Am J 41:352358.

https://doi.org/10.2136/sssaj1977.03615995004100020037x

Christl I, Kincker H, Kögel - Knabner I, et al. (2008) Chemical

\section{Open Access}

This article is licensed under a Creative Commons Attribution 4.o International License, which permits use, sharing, adaptation, distribution and reproduction in any medium or format, as long as you give appropriate credit to the original author(s) and the source, provide a link to the Creative Commons license, and indicate if changes were made. The images or other third party material in this article are included in the article's Creative Commons license, unless indicated otherwise in a credit line to the material. If material is not included in the article's Creative Commons license and your intended use is not permitted by statutory regulation or exceeds the permitted use, you will need to obtain permission directly from the copyright holder. To view a copy of this license, visit http://creativecommons.org/licenses/by/4.0/. heterogeneity of humic substances: characterization of size fractions obtained by hollow - fibre ultrafiltration. Eur J Soil Sci 51:617-625. https://doi.org/https://doi.org/10.1111/j.13652389.2000.00352.x

Da Silva RR, Lucena GN, MacHado ÂF, et al. (2018) Spectroscopic and elementary characterization of humic substances in organic substrates. Comun Sci 9:264-274. https://doi.org/10.14295/CS.v9i2.2734

Dean C, Kirkpatrick JB, Doyle RB, et al. (2020) The overlooked soil carbon under large, old trees. Geoderma 376:. https://doi.org/10.1016/j.geoderma.2020.114541

Drewnik M (2000) Ectohumus horizons and the rate of organic matter decomposition in the Carpathian soils. Pr Geogr 105:391-401

Erraji H, Afilal ME, Azim K, et al. (2017) Valorization of household anaerobic processed digestate: A case study of Morocco. J Mater Environ Sci 8:4024-4031.

Gami SK, Lauren JG, Duxbury JM (2009) Influence of soil texture and cultivation on carbon and nitrogen levels in soils of the eastern Indo-Gangetic Plains. Geoderma 153:304-311. https://doi.org/10.1016/j.geoderma.2009.08.003

Gill RA, Jackson RB (2000) Global patterns of root turnover for terrestrial ecosystems. New Phytol 147:13-31.

https://doi.org/10.1046/j.1469-8137.2000.00681.x

Giurov G, Artinova N (2001) Soil Science. Makros, Sofia. pp 132139.

Golębiowska D (2004) Absorption spectrometry in the UV-VIS range: parameters and methods of analyzing the absorption spectra of humic compounds. In: Gołębiowska D (ed.), Research Methods for Humic Substances in Aquatic and Terrestrial Ecosystems. AR, Szczecin, pp 15-26. (in Polish)

Gonet SS (1993) The structure of humic substances. Zesz Probl Post Nauk Roln 411:189-194 (in Polish)

Gonet SS, Dębska B (1998) Properties of humic acids developed 
during humification process of post-harvest plant residues. Environ Int 24:603-608.

https://doi.org/https://doi.org/10.1016/So16o-

4120(98)00034-8

Guangyin Z, Youcai Z (2017) Harvest of Bioenergy From Sewage Sludge by Anaerobic Digestion. In: Pollution Control and Resource Recovery. Elsevier, pp 181-273

Guggenberger G (2005) Humification and mineralization in soils. In: Varma A, Buscot F (eds.) Microorganisms in Soils: Roles in Genesis and Functions. SpringerNature, Berlin, Heidelberg. pp 85-106.

Guggenberger G, Zech W (1994) Dissolved organic carbon in forest floor leachates: simple degradation products or humic substances? Sci Total Environ 152:37-47.

https://doi.org/10.1016/0048-9697(94)90549-5

Guimarães DV, Gonzaga MIS, da Silva TO, et al. (2013) Soil organic matter pools and carbon fractions in soil under different land uses. Soil Tillage Res 126:177-182. https://doi.org/10.1016/j.still.2012.07.010

Hayes MHB, Swift RS (2001) Progress towards understanding aspects of composition and structure of humic substances. In: Swift RS, Spark KM (eds.), Understanding and Managing Organic Matter in Soils, Sediments, and Waters. IHSS, pp 3-16.

He X, Hou E, Liu Y, et al. (2016) Altitudinal patterns and controls of plant and soil nutrient concentrations and stoichiometry in subtropical China. Sci Rep 6:1-9. https://doi.org/10.1038/srep24261

Hejcman M, Hejcmanová P, Pavlů V, et al. (2012) Origin, history, management and plant species composition of grasslands in Central Europe - a review. In: Goliński P, Warda M, Stypiński P (eds.), Grassland - a European resource? Proceedings of the 24th General Meeting of the European Grassland Federation, Lublin, Poland, 3-7 June 2012. Polskie Towarzystwo Łąkarskie (Polish Grassland Society). pp 554-567.

IUSS Working Group WRB (2015) World reference base for soil resources 2014. International soil classification system for naming soils and creating legends for soil maps. Update 2015. World Soil Resources Reports No. 106. FAO, Rome, Italy

Jiang L, He Z, Liu J, et al (2019) Elevation gradient altered soil C, $\mathrm{N}$, and P Stoichiometry of pinus taiwanensis forest on Daiyun Mountain. Forests 10:1-15.

https://doi.org/10.3390/F10121089

Jiménez-González MA, Almendros G, Waggoner DC, et al. (2020) Assessment of the molecular composition of humic acid as an indicator of soil carbon levels by ultra-high-resolution mass spectrometric analysis. Org Geochem 143:104012. https://doi.org/10.1016/j.orggeochem.2020.104012

Kabała C, Karczewska A (2017) Methodology of laboratory analyzes of soils and plants, 8th edition. INoGOOE, UP, Wrocław, Poland. pp 23-24. (in Polish)

Kalbitz K, Solinger S, Park JH, et al. (2000) Controls on the dynamisc of dissolved organic matter in soils: a review. Soil Sci 164:277-304.

Kandeler E, Stemmer M, Gerzabek MH (2005) Role of Microorganisms in Carbon Cycling in Soils. In: Buscot F, Varma A (eds) Microorganisms in Soils: Roles in Genesis and Functions. Springer, Berlin Heidelberg New York, pp 139-158.

Kögel-Knabner I (1997) 13C and 15N NMR spectroscopy as a tool in soil organic matter studies. Geoderma 80:243-270.

https://doi.org/10.1016/So016-7061(97)0o055-4

Konen ME, Burras CL, Sandor JA (2003) Organic Carbon, Texture, and Quantitative Color Measurement Relationships for Cultivated Soils in North Central Iowa. Soil Sci Soc Am J 67:1823-1830. https://doi.org/10.2136/sssaj2003.1823

Kononowa M (1968) Organic substances of soil their structure properties and research methods. PWRiL, Warszawa, Poland. (in Polish)

Kubijowicz W (1927) Shepherd life in the Beskids Magóra. Prace Komisji Etnograficznej Polskiej Akademi Umiejętności Nr. 2, Kraków, Poland. (in Polish)

Kukuḷ I, Kḷavinš M, Nikodemus O, et al. (2019) Changes in soil organic matter and soil humic substances following the afforestation of former agricultural lands in the boreal-nemoral ecotone (Latvia). Geoderma Reg 16: eo0213.

https://doi.org/10.1016/j.geodrs.2019.eoo213

Kumada K (1987) Chemistry of Soil Organic Matter. Elsevier, Japan,Tokyo.

Li FB, Lu G De, Zhou XY, et al. (2015) Elevation and land use types have significant impacts on spatial variability of soil organic matter content in hani terraced field of Yuanyang County, China. Rice Sci 22:27-34.

https://doi.org/10.1016/j.rsci.2015.05.005

Lindbo D, Rabenhorst M, Rhoton E (1998) Quantifying hydric soil indicators with soil color. In: Rabenhorst (ed) Quantifying soil hydromorphology. SSSA Spec. Publ. 54. SSSA, Madison, WI, USA, pp 95-106.

Lityński T, Jurkowska H, Gorlach E (1976) Chemical-agricultural Analysis. PWN. (In Polish)

Martin D, Lal T, Sachdev CB, et al. (2010) Soil organic carbon storage changes with climate change, landform and land use conditions in Garhwal hills of the Indian Himalayan mountains. Agric Ecosyst Environ 138:64-73.

https://doi.org/10.1016/j.agee.2010.04.001

Mazurek R, Kowalska J, Gasiorek M, et al. (2016) Micromorphological and physico-chemical analyses of cultural layers in the urban soil of a medieval city - A case study from Krakow, Poland. Catena 141:73-84.

https://doi.org/10.1016/j.catena.2016.02.026

Mielnik L (2016) Characteristics of the humic acids (HA) from lake sediments as effect of UV-VIS spectal parameters application. Acta Sci Pol Trchnica Agrar 15:43-51.

Mikhailova EA, Stiglitz RY, Post CJ, et al. (2017) Predicting soil organic carbon and total nitrogen in the russian chernozem from depth and wireless color sensor measurements. Eurasian Soil Sci 50:1414-1419.

https://doi.org/10.1134/S106422931713004X

Mohinuzzaman M, Yuan J, Yang X, et al (2020) Insights into solubility of soil humic substances and their fluorescence characterisation in three characteristic soils. Sci Total Environ 720:137395.

https://doi.org/10.1016/j.scitotenv.2020.137395

Mostofa KMG, Jie Y, Sakugawa H, Liu CQ (2019) Equal treatment of different EEM data on PARAFAC modeling produces artifact fluorescent components that have misleading biogeochemical consequences. Environ Sci Technol 53:561-563. https://doi.org/10.1021/acs.est.8bo6647

Müller M, Oelmann Y, Schickhoff U, et al (2017) Himalayan treeline soil and foliar C:N:P stoichiometry indicate nutrient shortage with elevation. Geoderma 291:21-32. https://doi.org/10.1016/j.geoderma.2016.12.015

Navarrete IA, Tsutsuki K, Navarrete RA (2010) Humus composition and the structural characteristics of humic substances in soils under different land uses in Leyte, Philippines. Soil Sci Plant Nutr 56:289-296. https://doi.org/10.1111/j.1747-0765.2010.00455.x

Ni X, Yang W, Tan B, et al. (2016) Forest gaps slow the sequestration of soil organic matter: A humification experiment with six foliar litters in an alpine forest. Sci Rep 6:1-13. https://doi.org/10.1038/srep19744

Niemyska-Łukaszuk J, Miechówka A, Zaleski T (2002) The soils of Pieniny National Park and their threats. Pieniny - Przyr i Człowiek 90:79-90. (in Polish)

Novák J, Lukas V, Křen J (2018) Estimation of soil properties based on soil colour index. Agric Conspec Sci 83:71-76.

Nowosad M (1995) Outlines of climate of the Bieszczady National Park and its buffer zone in line of previous studies. Rocz Bieszczadzkie 4:163-183.

Obrebska-Starklowa B, Hess M, Olecki Z, et al. (1995) Climate. In: Polish Carpathians, nature, man and his activities. UJ, Kraków, pp 31-47. (in Polish)

Orlov D (1983) Soils Chemistry. Moscow State University, Moscow.

Oyama M, Takehara H (1970) Revised Standard Soil Color Charts. Research Council for Agriculture, Forestry and Fisheries, Japan. 
Oyarzún CE, Godoy R, Staelens J, et al. (2011) Seasonal and annual throughfall and stemflow in Andean temperate rainforests. Hydrol Process 25:623-633.

https://doi.org/10.1002/hyp.7850

Panettieri M, Kincker H, Murillo J, et al. (2014) Soil organic matter degradation in an agricultural chronosequence under different tillage regimes evaluated by organic matter pools, enzymatic activities and CPMAS ${ }^{13} \mathrm{C}$ NMR. Soil Biol Biochem 78:170-181.

https://doi.org/https://doi.org/10.1016/j.soilbio.2014.07.021

Perzanowska J (2004) Climate of the Pieniny Mointains. Stud Naturae 49:21-32

Pospíśilová L', Fasurová N, Jurica L (2014) Fractionation of humus and optical properties of humic acids originating from different soil types. Acta Univ Agric Silvic Mendelianae Brun 54:45-52. https://doi.org/10.11118/actaun200654040045

Quideau SA, Anderson MA, Graham RC, et al (2000) Soil organic matter processes: Characterization by $13 \mathrm{C}$ NMR and $14 \mathrm{C}$ measurements. For Ecol Manage 138:19-27.

https://doi.org/10.1016/So378-1127(00)00409-6

Reddy SB, Nagaraja MS, Raj TSP, et al (2012) Soil humic and fulvic acid fractions under different land use systems. Madras Agric J 99:507-510.

Saiz-Jimenez C (1996) The chemical structure of humic substances. In: Humic Substances in Terrestrial Ecosystems. Elsevier, pp 1-44.

Schmidt MWI, Torn MS, Abiven S, et al. (2011) Persistence of soil organic matter as an ecosystem property. Nature 478:49-56. https://doi.org/10.1038/nature10386

Schnitzer M (1999) A lifetime perspective on the chemistry of soil organic matter. Adv Agron 68:1-58. https://doi.org/10.1016/Soo65-2113(08)60842-1

Schnitzer M, Khan S (1972) Humic Substances in the Environment. Marcel Dekker, New York, USA.

Skiba S (1999) Characteristics of the soils in Bieszczady National Park. Zesz Probl Post Nauk Roln 467:21-32. (in Polish)

Skiba S, Drewnik M (2000) Soil cover of the Magura National Park ( the Carpathians, Beskid Niski Mts ). Rocz Bieszczadzkie 9:183-195. (in Polish)

Sokołowska J, Józefowska A, Woźnica K, et al. (2020) Succession from meadow to mature forest: Impacts on soil biological, chemical and physical properties-Evidence from the Pieniny Mountains, Poland. Catena 189: 104503. https://doi.org/10.1016/j.catena.2020.104503

Stępień-Sałek M (2004) Magura National Park. Przyr Pol 02:1618. (in Polish)

Stevenson FJ (1994) Humus chemistry: genesis, composition, reactions. John Wiley \& Sons, Inc., New York, USA.

Suhett A., MacCord F, Amado A., et al. (2004) Photodegradation of dissolved organic carbon in humic coastal lagons. In: Neto L, Milori DMB, da Silva WT (eds.), Humic Substances And Soil And Water Environment. IHSS, Embrapa. pp 61-69.

Sun C, Liu J, Wang Y, et al. (2012) Effect of long-term cultivation on soil organic carbon fractions and metal distribution in humic and fulvic acid in black soil, Northeast China. Soil Res 50:562. https://doi.org/10.1071/SR12100

Susic M (2016) Replenishing humic acids in agricultural soils. Agronomy 6(4):45.

https://doi.org/10.3390/agronomy6040045

Sutton R, Sposito G (2005) Molecular structure in soil humic substances: the new view. Environ Sci Technol 39:9009-9015. https://doi.org/https://doi.org/10.1021/es050778q

Tadini A, Constantino I, Nuzzo A, et al. (2015) Characterization of typical aquatic humic substances in areas of sugarcane cultivation in Brazil using tetramethylammonium hydroxide thermochemolysis. Sci Total Environ 518-519:201-208.

https://doi.org/https://doi.org/10.1016/j.scitotenv.2015.02.103

Tan KT (2005) Soil sampling, preparation and analysis. Taylor \& Francis Group, Boca Raton, USA.

Thomsen IK, Kruse T, Bruun S, et al. (2008) Characteristics of soil carbon buried for 3300 Years in a bronze age burial mound. Soil Biol Biochem 72:1292-1298.

https://doi.org/https://doi.org/10.2136/sssaj2007.0348

Ukalska-Jaruga A, Klimkowicz-Pawlas A, Smreczak B (2019) Characterization of organic matter fractions in the top layer of soils under different land uses in Central-Eastern Europe. Soil Use Manag 35:595-606. https://doi.org/10.1111/sum.12514

Vázquez C, Iriarte AG, Merlo C, et al. (2016) Land use impact on chemical and spectroscopical characteristics of soil organic matter in an arid ecosystem. Environ Earth Sci 75:. https://doi.org/10.1007/s12665-016-5655-9

Viscarra Rossel R, Minasny B, Roudier P, et al. (2006) Colour space models for soil science. Geoderma 133:320-337. https://doi.org/https://doi.org/10.1016/j.geoderma.2005.07.017

Vodyanitskii YN, Kirillova NP (2016) Application of the CIE$\mathrm{L}^{*} \mathrm{a}^{*} \mathrm{~b}^{*}$ system to characterize soil color. Eurasian Soil Sci 49:1259-1268. https://doi.org/10.1134/S1064229316110107

Vodyanitskii YN, Savichev AT (2017) The influence of organic matter on soil color using the regression equations of optical parameters in the system CIE- L*a*b*. Ann Agrar Sci 15:380385. https://doi.org/10.1016/j.aasci.2017.05.023

Wang H, Chou C, Chiou C, et al. (2016a) Humic acid composition and characteristics of soil organic matter in relation to the elevation gradient of Moso bamboo plantations. PLOS ONE 11(9): e0162193.

https://doi.org/10.1371/journal.pone.0162193

Wang H, Tian G, Chiu C (2016b) Invasion of moso bamboo into a Japanese cedar plantation affects the chemical composition and humification of soil organic matter. Nat Publ Gr 1-6. https://doi.org/10.1038/srep32211

Weber $J$ (2020) Humic substances and their role in the environment. Agriculture 03-08. https://doi.org/10.1016/0167-8809(90)90135-Z

Weber J, Chen Y, Jamroz E, et al. (2018) Preface: humic substances in the environment. J Soils Sediments 18:2665-2667. https://doi.org/10.1007/s11368-018-2052-x

Wills SA, Burras CL, Sandor JA (2007) Prediction of soil organic carbon content using field and laboratory measurements of soil color. Soil Sci Soc Am J 71:380-388. https://doi.org/10.2136/sssaj2005.0384

Wilson BR, Moffat AJ, Nortcliff S (1997) The nature of three ancient woodland soils in southern England. $J$ Biogeogr 24:633-646.

https://doi.org/10.1111/j.1365-2699.1997.tbooo74.x

Wnuk E, Waśko A, Walkiewicz A, et al. (2020) The effects of humic substances on DNA isolation from soils. PeerJ 8: e9378. https://doi.org/10.7717/peerj.9378

Zalba P, Amiotti N, Galantini JA, et al. (2016) Soil humic and fulvic acids from different land-use systems evaluated by E4/E6 ratios. Commun Soil Sci Plant Anal 47:1675-1679. https://doi.org/https://doi.org/10.1080/00103624.2016.1206558

Zarzycki J, Korzeniak J (2013) Meadows in the Polish Carpathians - present state , changes and preservation prospects. Rocz Bieszczadzkie 21:18-34 (in Polish)

Zhiyanski M, Glushkova M, Kirova L, et al. (2017) Quantitative and qualitative features of soil humus in mountain treeline ecosystems. Silva Balc 18:5-23. 